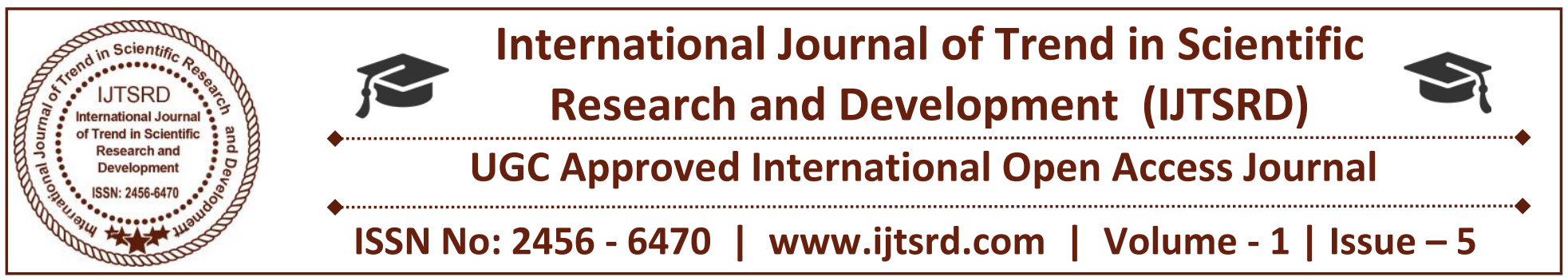

\title{
Qadriya Sufis: Restoration of Peace in Kashmir Society
}

\author{
Syed Damsaz Ali Andrabi, \\ Social Scientist, Department of Higher Education J \& K
}

\section{ABSTRACT}

Qadriya Sufis have left a deep and remarkable impression on the society of Kashmir. Immediately after their arrival in valley they engaged themselves for the betterment of people irrespective of religion. They influenced people through their morals, pure thoughts, kindness and humanistic approach. People of Silsila were men of intellect, creative mind as, administrators as well as scholars, medical practitioners, artisans, economists etc. The earned groups called land tillers and artisan were influenced by them. Learning has been defined by them as the highest attainment of humanity, a way leading to right conduct and cultivation of virtue. On the whole Qadriya Sufis succeeded in bringing marvellous change in the thought and life of all people whether people of faith or others. In general they made people to understand the relation between God and man. Concept of humanism developed in the valley of Kashmir. Their teachings and writings proved to be a great source of inspiration not only to rulers but also to the subsequent generations. They were having no lust for power and have not indulged in the state politics. Even at present their growing influence is visible in Kashmiri society.

Keywords: Sufis, Peace, Rituals, Brotherhood, Economy, Culture

\section{INTRODUCTION}

Religious contacts have a longer lasting life and an immense potential for cementing the bonds between the people. As preachers of religion have an tremendous access to each and every strata of society. While carrying the flag of religion as peace they proved to be more moderate and also acted as interpreters of welfare among the people.
Development and numerical strength was added by the Qadriya Sufis to the areas where they got settled especially in the valley of Kashmir, with an increase in manufacturing of handicrafts and arts. Each and every aspect was transformed be it religion, art, architecture, calligraphy, language and literature, educational system and technology. Their continuous movement in valley also facilitated the exchange of ideas apart from the religion which is still flourishing among the dominant rituals practised by the people. Since they constituted an important stratum of the prestigious sections of the society, their representation of Islam here won more and more recruits as it was closer to the traditional ethos which deeply embedded mentality of the local people. Although they arrived in valley during the progressive stage of Islam, still respectable position was managed by preachers of Qadriya Silsila.

The Qadriya Sufis were the last of the major Sufi Silsilas to reach the valley. Qadriya Sufis reached in the valley during the second half of sixteenth century. Syed Nimatullah Shah Qadri (d.1582.A.D) was the first Sufi of the Silsila here. He migrated to Kashmir from Hisar in Punjab during the rule of Chaks (156186.A.D). His presence proved very auspicious for the Sufis of the Silsila to enter into the valley. They settled in the heart of Srinagar city as well in rural areas of the valley. Srinagar was the biggest town and seat of power. In the hot seat of political power it was difficult to remain aloof from political influence, but the Qadriyas maintained a respectful distance from the political activities. As compared to other Sufi Silsilas the number of Qadriya Shrines in the heart of Srinagar is very high. Through the centuries their influence kept growing in all parts of the valley. More than half of important Shrines of Sufis in the valley 
belong to Qadriyas. The highest concentration of Qadriya Sufis remained in all parts the valley. In valley of Kashmir Khanqahi Pir Dastgir at Khanyar in Srinagar became the centre of Qadriya Sufis and a place of profound veneration, perfection and excellence for future generations.

To understand the influence of Qadriyas in the valley one has to see their overall presence in the valley which suggest the prevailing dominant philosophy or ideology in the valley. As a first indicator we look at the symbol and practices followed by people. A survey of the religious structures of Shrines and Khanqahs of Sufis gives some indication. Out of a total around one hundred and two Sufi Shrines around fifty two exclusively belong to Qadriyas and the rest are divided among Suhrawardi ${ }^{1}$, Kubravi ${ }^{2}$, Naqshbandi ${ }^{3}$ and Rishi ${ }^{4}$ orders. Similarly out of around forty eight Khanqahs around twenty eight belong to Qadriya Sufis and rest to all other orders.

Another significant feature in the Kashmir valley is almost complete absence of non Muslim backward and dalit groups. Most of the non Muslims belong to Brahmanical or other high caste groups. It signifies that the adoption of Islam was most enthusiastically done by the peasants, artisans and other low caste groups. Most of the Qadriya ${ }^{5}$ Sufis in urban areas were very close to artisan groups and lower strata of people. There are repeated references of the active role played by Sufis in encouraging people to take up new crafts. A quick survey of crafts and craftsmen of Kashmir we notice that quite a number of them were introduced in the valley during the medieval period. The craftsmen of new crafts were also Kashmiris and were drawn from traditional artisans of prevalent crafts of wood, iron, gold, pottery, leather work and metal work etc. New crafts introduced in the valley, which are still practiced are, Zardoozi with Golden thread (Tila work), Embroidery work on Shawls (Sozni work), Carpet Weaving (Qalin Bafs), Shawl Weavers (Shawl Bafs), Paper Machi (Zargar), Wood Carving (Najar), Agricultural tools(Ahangar),Oil Presser (Teli) etc. Almost all the craftsmen express their allegiance to the popular religious practices which are identified with Sufis. Majority of them belong to Qadriya Silsila. The people belonging to various artisan centres and lower strata did not have much access to the socio-religious and cultural life in the towns. As in case of Bhakti, which found many eminent Saints among these groups, Sufism also appealed to them. The simplicity of the message of love towards God and uncomplicated devotional practices and access to a regular guide helped Qadriya Sufis in attracting people to Islamic religious fold became a gradual process. It in some ways offered these groups a hope and promise of a more egalitarian social existence. Syed Mohammad Mubarik Hussaini son of Jafar-al-Makki lists the following as the major causes $^{6}$ of conversion, i) desire to get merit in this world, ii) fear of death and enslavement, iii) preaching's of Muslims and, iv) bigotry of old faiths. In the case of Kashmir the Qadriyas did believe in preaching and for urban groups conversion seemed a better economic and social deal, through participating in new craft areas and a faith which promises social equality. In this context it is also pointed out ?there was another reason for conversion through the process of acculturation particularly among the lower strata of society. Conversion through acculturation is a long process and can be distinguished from formal conversion-the latter might be called lconscious and formal conversion? while the former ?conversion through the gradual and slow adoption of Islamic way of life? ${ }^{7}$. The similar process seems to have carried the Islam to the rural areas. Here the role of the Qadriya Sufis is very evident. As noticed earlier they were the last to enter the valley but first to reach the interior rural areas. In rural areas the presence of Qadriya Shrines is much higher than of any other Sufi denomination (in Pulwama ${ }^{8}$ six out of nine, in Baramulla $^{9}$ five out of ten, Budgam ${ }^{10}$ three out of four, Kupwara ${ }^{11}$ one out of two only in Anantnag ${ }^{12}$ Rishi order has four out of six). Adoption of Islam by the Gujars the most prominent tribe in the valley shows the trend as elsewhere in the case of tribes, the whole tribe of the region seems to have adopted the Islam. The life in the rural areas revolves around the Pirs most of who belong to Qadriya Silsila. They are consulted and provide guidance on all major decisions of the social and economic life of people. Starting a new business, building a house, fixing a marriage or other issues of day to day life the Pir plays a role. Social life beyond the family shows a close connection with the Sufi ways and a result of their influence over a long period of time.

The efforts of the Sufi Saints have influenced the society in all diverse aspects. In spite of having an elaborate code of rituals and ceremonies with regard to birth, marriage, building a house, giving names to children and other day to day engagements Qadriya Pirs are consulted by the common masses on important occasions. In most cases the Muslims as 
well as non Muslims both have faith in the Shrines and the Pirs. This is obvious and clear that the age old tradition of having a Pir and trust in Shrines played a larger part in the social life of people and continues even at present. Even the eleventh (Qadriya tradition) of every month of Islamic calendar is still celebrated by all the Kashmiris to fulfil their wishes. On this very particular day the people are invited and they used to sit together to recite the verses of Quran. At times attempts were made to wean away people from the mystic influence. The more orthodox followers of Islam organized under various organizations have tried to oppose the practices followed by the people under the Sufi ways of practicing Islam, terming it unIslamic, but the influence and belief of people is deep enough. Though the religion of Majority of people was Islam still a group of people raised their voice against the prevalent religious practices under the leadership of Mohammad Hussain a resident of Srinagar during the reign of Maharaja Ranbir Singh (1857-1885.A.D).His main opposition was against the profession of Pir Muridi, ?]superstitious rituals? and more importantly against the worship of Asthans (Shrines). But the opposition to his ideas was so strong that Maharaja was forced to give an order for Hessian's expulsion from the state. Later on in early twenties the Anjuman-i-Ahli Hadith, which came in the light under the guidance of Maulvi Ghulam Nabi Mubaraki and Maulvi Nuru'd-din have confined themselves to the text of the Quran and Hadith . They advocated the abolition of anti Islamic practices such as worship of Pirs among the Muslims and it is very interesting that people of this thought are at present dubbed as Kutas (un-believers) by the majority of Kashmiri people. Even at present there are groups who criticize these practices in the valley but they are keeping low and are not in a position to raise their voice against the Shrine.

The Shrines of Srinagar are under Wakf Board run by the state government and village Shrines are under village level committees. Some efforts were made to utilize the offerings for educational purpose. Islamic University was established and also numbers of schools were opened and were kept under the special care of Wakf Board. The huge income received by village Shrines is not utilized properly. If the money will be spent on opening of institutions the position would have been entirely different. So there is a dire need of reformation of Kashmiri society, so that the offerings may be used for proper development . Need of the hour is to revive the approach of Qadriya Sufis, so that the concept of charity can be boosted again.

They proved as influential agency because besides preachers, they were also able administrators, poets, historians, medical practitioners, urban artisans etc. It is obvious that the historical role of Qadriya Sufis did not lie only in liberalising orthodox Islam but in introducing ethics into the life of the individual as well as in structuring individual and collective Muslim identities as embodiments of spiritual and social stability. The way in which the abodes of Qadriya Sufis became the holy places suggests their wider contribution they have rendered to Kashmiri society with a unique and separate identity.

Conclusion: Their philosophy has ultimately brought peace and prosperity among all sections of society. With the result a new social setup based on moral values got cropped up. Concept of brotherhood developed within the society through the observance of rituals. Their message was not confined to one section, but was universal in nature. Qadriya Sufis succeeded in changing the total outlook of Kashmiri society .In general people were influenced and visited their Shrines irrespective of religion.

\section{NOTES AND REFERENCES}

1) Pandit Amin , Tarikhi Kashmir, Srinagar, 1984, pp. 113.

2) Nuri Abdul Wahab , Fatuhati Kubriya, Mss,P.79, Research library University of Srinagar Kashmir.

3) John Subhan A, Sufism its Saints and Shrines, New Delhi 1999, P.187.

4) Ahmad Sheikh, Alamdar Kashmir, Srinagar, 1997, pp. 42, 194.

5) Qadri Hussain Mohd, Fatuhati Qadriya, Mss, pp.207-208, Research library University of Srinagar Kashmir.

6) S.Inayat A. Zaidi and Sunita Zaidi, Conversion to Islam and Formation of Castes in Medieval Rajasthan?in Art and Culture ed. A. Jan Qaisar and S. P. Varma, Delhi, 1993, pp. 29 \& fn 22.

7) S. Inayat. A. Zaidi, Ibid, pp. 29.

8) Pulwama district came into being in the year 1979.A.D. The district is situated in the north of Srinagar at a distance of $32 \mathrm{Kms}$. 
9) Baramulla is almost $52 \mathrm{Kms}$ from Srinagar and is surrounded in east by Kupwara.

10) A name of the District headquarters. It is situated in the North West of Srinagar city at a distance of $10 \mathrm{Kms}$.

11) Kupwara district came into being in the year 1979 A.D. It is $90 \mathrm{Kms}$ from Srinagar in the east and south lie Baramulla in the west and north there is LOC which separates it from Muzaffarabad Pakistan.

12) The history of district dates back to the times of Dogra rule. One has to cover a distance of 55 Kms. from Srinagar to reach Anantnag .It is bounded by Srinagar district in the north, Pulwama district in the northwest and Kargil district in the north. 